\title{
Physical properties of pizza Mozzarella cheese manufactured under different cheese-making conditions
}

\author{
V. Banville, ${ }^{*}$ P. Morin, $\dagger$ Y. Pouliot, ${ }^{*}$ and M. Britten $\ddagger^{1}$ \\ *STELA Dairy Research Group, Institute of Nutraceuticals and Functional Foods (INAF), Université Laval, Quebec City, QC, Canada, G1K 7P4 \\ †Research and Development Centre, Agropur Cooperative, St-Hubert, QC, Canada, J3Z 1G5 \\ ¥Food Research and Development Centre, Agriculture and Agri-Food Canada, 3600 Casavant Blvd. W., Saint-Hyacinthe, QC, Canada, J2S 8E3
}

\section{ABSTRACT}

The effect of manufacturing factors on the shreddability and meltability of pizza Mozzarella cheese was studied. Four experimental cheeses were produced with 2 concentrations of denatured whey protein added to milk (0 or $0.25 \%$ ) and 2 renneting $\mathrm{pH}$ values (6.4 or $6.5)$. The cheeses were aged 8,22 , or $36 \mathrm{~d}$ before testing. Shreddability was assessed by the presence of fines, size of the shreds, and adhesion to the blade after shredding at 4,13 , or $22^{\circ} \mathrm{C}$. A semi-empirical method was developed to measure the matting behavior of shreds by simulating industrial bulk packaging. Rheological measurements were performed on cheeses with and without a premelting treatment to assess melt and postmelt cheese physical properties. Lowering the $\mathrm{pH}$ of milk at renneting and aging the cheeses generally decreased the fines production during shredding. Adding whey protein to the cheeses also altered the fines production, but the effect varied depending on the renneting and aging conditions. The shred size distribution, adhesion to the blade, and matting behavior of the cheeses were adversely affected by increased temperature at shredding. The melting profiles obtained by rheological measurements showed that better meltability can be achieved by lowering the $\mathrm{pH}$ of milk at renneting or aging the cheese. The premelted cheeses were found to be softer at low temperatures $\left(<40^{\circ} \mathrm{C}\right)$ and harder at high temperatures $\left(>50^{\circ} \mathrm{C}\right)$ compared with the cheeses that had not undergone the premelting treatment. Understanding and controlling milk standardization, curd acidification, and cheese aging are essential for the production of Mozzarella cheese with desirable shreddability and meltability.

Key words: Mozzarella cheese, physical property, colloidal calcium, whey protein

Received October 26, 2012.

Accepted April 10, 2013.

${ }^{1}$ Corresponding author: michel.britten@agr.gc.ca

\section{INTRODUCTION}

Low-moisture part-skim pizza Mozzarella is a variety of pasta filata cheese used extensively as a topping on baked dishes in North America. Ingredient cheeses such as Mozzarella must exhibit key physical attributes in both the unmelted and melted states (Lucey, 2008).

Pizza Mozzarella cheese is almost systematically shredded, cut or diced to improve its handling and enhance its meltability (Gunasekaran and Ak, 2002). Shreddability is a broad term that includes physical attributes such as the ease of machinability, the shape and integrity of shreds, the propensity of shreds to mat, and the excessive production of fines during shredding (Childs et al., 2007). Good shredding behavior is observed in a relatively narrow range of textural properties and is not fully understood, or controlled, by cheese manufacturers. Soft cheese usually shows poor shredding characteristics because it sticks to the blade, forms gummy balls of cheese, and produces shreds that tend to mat together. On the other end of the spectrum, firm and dry Mozzarella cheese easily shatters into fines (Kindstedt, 1995). Unfortunately, few methods are available to assess the shredding behavior of cheese. The quality grading of shreds based on visual evaluation has been used by some researchers (Apostolopoulos and Marshall, 1994; Chen, 2003; Ni and Guansekaran, 2004). In an effort to assess the defects observed during the shredding process, Childs et al. (2007) empirically measured the fines production and the adhesion to the blade of cheeses during shredding. These attributes, along with the matting of shreds, are still considered the most common problems, and little is known about the factors that cause them.

Unlike shredding behavior, the physical properties of cheese in its melted state have been studied extensively. When Mozzarella cheese is baked, its quality is associated with extent of flow, stretchability, free-oil formation, blistering, and browning (Gunasekaran and $\mathrm{Ak}$, 2002). Metzger and Barbano (1999) also pointed out the importance of the postmelt texture of Mozzarella cheese in regard to its quality and acceptability. How- 
ever, the postmelt texture of cheese has received little attention from researchers.

More than ever, the growing demand for tailored cheese ingredients requires a better understanding of the effect of cheese-making processing variables on the physical properties and microstructure of cheese. Freshly manufactured Mozzarella cheese exhibits the typical protein fiber orientation and melts poorly. The hydration of the protein matrix and the proteolysis that occur conjointly during the short aging of Mozzarella cheese dramatically change the microstructure and texture of the cheese (McMahon et al., 1999). For control of the baking characteristics, many studies also demonstrated the primary importance of the calcium content in Mozzarella cheese, but most important is the partitioning of the calcium between insoluble and soluble states (Joshi et al., 2003; Johnson and Lucey, 2006; Choi et al., 2008). The effect of the addition of milk ingredients on cheese physical properties has been studied to some degree in full-fat cheeses (Punidadas et al., 1999; Mead and Roupas, 2001) but most interest has focused on low-fat cheeses (Zisu and Shah, 2005; Ismail et al., 2011; Schenkel et al., 2011). Milk ingredients, particularly denatured whey protein (WP) concentrate, are widely used in the industrial production of Canadian pizza Mozzarella cheese to increase yield and nutrient value at low cost (Hinrichs, 2001). The aim of the present study was, therefore, to evaluate the effect of adding denatured WP and controlling cheese mineralization through the renneting $\mathrm{pH}$ on the shreddability and rheological properties of pizza Mozzarella cheese.

\section{MATERIALS AND METHODS}

\section{Milk Standardization}

Cheese milk was formulated from (1) raw skim milk (2.5\% wt/wt casein), (2) milk protein concentrate $(\sim 77 \%$ wt/wt casein on a dry basis; $872 \mathrm{~B}$, lots L610009 and L610009; Ingrédia SA, Arras, France) rehydrated at $10.1 \%$ (wt/wt) casein in water, (3) fresh cream $(1.5 \% \mathrm{wt} / \mathrm{wt}$ casein; $\sim 40 \% \mathrm{vol} / \mathrm{vol}$ milk fat), and (4) denatured WP concentrate $(\sim 55 \% \mathrm{wt} / \mathrm{wt}$ protein on a dry basis; Agropur, Granby, QC, Canada) rehydrated at $10.5 \%$ (wt/wt) protein in water. Casein concentration and fat-to-protein ratio in standardized milk were respectively $3.0 \%$ (wt/wt) and 0.85 and the concentration of protein from denatured WP concentrate was fixed to 0 or $0.25 \%$ (wt/wt). Total protein concentration in cheese milk with and without added denatured WP were respectively 3.95 and $3.70 \%$ (wt/wt). The standardized milk was pasteurized at $74^{\circ} \mathrm{C}$ for $16 \mathrm{~s}$ before cheese making.

\section{Manufacture of Pizza Mozzarella Cheese}

Cheese milk $(350 \mathrm{~kg})$ was supplemented with calcium chloride $(0.0063 \% \mathrm{wt} / \mathrm{wt})$ and ripened with a direct-in-vat thermophile starter culture $(0.104 \%$ wt/ wt, Easy-Set i420; Chr. Hansen, Milwaukee, WI) until the appropriate renneting $\mathrm{pH}$ was reached. Coagulant (Fromase XLG; DSM Food Specialties Inc., Eagleville, PA) was added to the milk $(0.0075 \% \mathrm{vol} / \mathrm{wt})$ at a renneting $\mathrm{pH}$ of 6.4 or 6.5 . The setting period varied from 8 to $20 \mathrm{~min}$, depending on the gelling behavior. The coagulum was cut and healed for $5 \mathrm{~min}$. Then, the curd-whey temperature was raised $\left(0.2^{\circ} \mathrm{C} / \mathrm{min}\right)$ to $40^{\circ} \mathrm{C}$ under low agitation. The whey was drained when the $\mathrm{pH}$ decreased 0.5 units below the renneting $\mathrm{pH}$. The drained curd was cheddarized (30 to $60 \mathrm{~min}$ ) to a fixed $\mathrm{pH}$ value of 5.2. The acidified curd was milled and then knitted in hot water $\left(65^{\circ} \mathrm{C}\right)$ with a pilot-scale cooker/ stretcher (JN-500 CS; Johnson/Nelles Corp., Windsor, WI). The rotational speed of horizontal and vertical screws was respectively 6 and $8 \mathrm{rpm}$ and residence time was approximately $5 \mathrm{~min}$. The cheese reached approximately $55^{\circ} \mathrm{C}$ at molding. Cheese obtained from the beginning and the end of the cooking/stretching process was discarded. Twelve cheese blocks $(26.5 \times 9.5 \times$ $9.5 \mathrm{~cm}$ ) of approximately $2.3 \mathrm{~kg}$ each were molded and brined in saturated sodium chloride solution $(\sim 24 \% \mathrm{wt} /$ wt, $4^{\circ} \mathrm{C}$ ) for $4 \mathrm{~h}$. The cheese blocks were vacuum sealed and stored at $4^{\circ} \mathrm{C}$. Two vats were available for cheese production and the 4 treatments (2 WP concentrations $\times 2$ renneting $\mathrm{pH}$ ) were performed from the same batch of milk within $72 \mathrm{~h}$. Cheese productions were repeated 3 times within a month.

\section{Chemical Analysis of Cheese}

For compositional analyses, one cheese block was cut in 4 symmetrical parts and one part was finely grated using a food processor. The moisture content was determined by the oven-drying method (Marshall, 1992). Ash was measured by incineration in a muffle furnace at $550^{\circ} \mathrm{C}$ for $12 \mathrm{~h}$. Water-soluble nitrogen was reported as a percentage of total nitrogen (WSN/TN\%) to monitor proteolysis of the cheese during aging (Watkinson et al., 2001). The nitrogen content was determined using the macro-Kjeldahl method, and total protein was calculated using a protein conversion factor of 6.38 (Marshall, 1992). The lipid content was obtained by the Mojonnier method (Marshall, 1992). The sodium chloride content was determined using a Chloride Analyzer 926 (Sherwood Scientific Ltd., Cambridge, UK) and the $\mathrm{pH}$ of the cheese was measured with an AR15 Accumet pH meter (Fisher Scientific, Ottawa, ON, Canada). 
The colloidal calcium (CC) content in the cheese was measured by the method developed by Rémillard and Britten (2011). The retention coefficient in the cheeses of the species $n$, the protein or fat, was calculated as follows:

Retention coefficient of $n=100-\left(\frac{n \% \text { in whey }}{n \% \text { in cheese milk }}\right) \times 100$.

Milk and whey composition was measured by infrared spectrometry (MilkoScan FT-120; Foss Electric, Eden Prairie, MN).

\section{Physical Properties of Cheese}

Shreddability of Pizza Mozzarella Cheese. The external layer of a cheese block was carefully trimmed and 2 identical cheese slabs were cut $(25 \times 9 \times 4 \mathrm{~cm})$ using a metal guide and a cheese wire. Four symmetrical samples $(9 \times 4 \times 3.5 \mathrm{~cm})$ were obtained from the ends of the 2 slabs. Each cheese sample was shredded under constant load $(1.25 \mathrm{~kg})$ in a household food processor (FP-12DCC; Cuisinart, Woodbridge, ON, Canada) equipped with a circular shredding blade $(5 \times 10-\mathrm{mm}$ openings). Cheese residue adhering to the blade was determined gravimetrically. The shredded cheese was transferred to the top of a stacking sieve [American Society for Testing and Materials (ASTM) specification no. 4, 6, and 10; Retsch Inc., Newtown, PA] and mechanically shaken for $60 \mathrm{~s}$ at 278 oscillations and $150 \pm 10$ taps per minute (Ro-Tap RX-29 sieve shaker; W.S. Tyler, Mentor, OH). The cheese fractions retained by the mesh sieves with $22.26-, 11.22-$, and $4.00-\mathrm{mm}^{2}$ openings were classified as long, medium, and small shreds, respectively. Cheese particles passing through the mesh with $4.00-\mathrm{mm}^{2}$ openings were classified as fines and reported as a proportion of the total weight of the shredded cheese. The fines production, the size distribution of the shreds, and the adhesion of cheese to the blade were used as indicators of shreddability.

Matting of Shreds. The preparation of shred cakes was inspired by Akbulut et al. (2011) and simulated the behavior of shreds under bulk packaging conditions. The long and medium shreds collected from the shredding experiment were stored at 4,13 , or $22^{\circ} \mathrm{C}$ for $1 \mathrm{~h}$. Then, $15 \mathrm{~g}$ of shredded cheese was placed into a plastic cylinder (25-mm i.d.) that was capped on one end, and the cheese was gently compacted with a freemoving piston to a constant volume of $30 \mathrm{~cm}^{3}$. Then, the cylinder was set vertically on its piston and stored at $4^{\circ} \mathrm{C}$ for $18 \mathrm{~h}$. The shred cake was unmolded onto the lower plate of a TA-XT2 texture analyzer (Stable Micro Systems, Scarsdale, NY). The matting behavior was measured by the penetration of a conical stainless steel tool $\left(20^{\circ}\right.$ angle $)$ at constant speed $(0.5 \mathrm{~mm} / \mathrm{s})$. The penetration force (in N) was reported against the volume deformation induced by the cone inside the shred cake.

Rheological Properties of Pizza Mozzarella Cheese. Dynamic oscillatory measurements were performed using a strain-controlled rheometer (Physica MCR 301; Anton Paar GmbH, Graz, Austria) equipped with 25-mm parallel plates (PP25; Anton Paar GmbH). Cylindrical cheese samples (25-mm diameter and 2-mm height) were carefully cut from the center portion of the cheese slabs using a cork borer and a cheese-cutting wire. The cheese disks were tested immediately after sampling. Fine-grade sandpaper (Grade 180B) was glued to the rheometer plates to prevent slippage, and a protection hood with a solvent trap (17780; Anton Paar $\mathrm{GmbH}$ ) covered the samples during the test. The cheese disks were compressed at $1 \mathrm{~N}$ normal force for a 5-min equilibration period before the temperaturesweep experiment started. The temperature was raised from 5 to $80^{\circ} \mathrm{C}$ at a rate of $5^{\circ} \mathrm{C} / \mathrm{min}$ while constant strain amplitude $(0.1 \%)$ was applied on the samples at an oscillation frequency of $1 \mathrm{~Hz}$. The complex modulus $\left(\mathbf{G}^{*}\right)$ and the phase angle $(\boldsymbol{\delta})$ were recorded and plotted against the temperature to obtain the cheese melting profile. The softening point, the temperature recorded at $\delta=45^{\circ}$, was also extracted from the melting profile data. Full descriptions of the rheological parameters used in this study can be found elsewhere (Gunasekaran and Ak, 2002; Lucey et al., 2003; Everett and Auty, 2008). The melting profile was also determined on premelted cheeses, which were prepared as follows: cheese disks were sampled and vacuum-sealed (VAK*3.0R; Winpak, Winnipeg, MB, Canada). The cheeses were then immersed in hot water $\left(90^{\circ} \mathrm{C}\right)$ for 15 min and cooled to $4^{\circ} \mathrm{C}$. The analyses of the premelted cheeses were performed 90 min after heat treatment.

\section{Experimental Design and Statistical Analysis}

Main Treatments. Pizza Mozzarella cheeses were randomly produced using 2 renneting $\mathrm{pH}$ values $(6.4$ and 6.5 ) and 2 added WP concentrations ( 0 and $0.25 \%$ ) according to a factorial experimental design repeated 3 times.

Shredding Experiment. The 4 cheeses were tested for compositional properties (WSN/TN\% and CC) and shredding properties (fines production, size distribution of shreds, adhesion to the blade, and matting behavior) at 8,22 , and $36 \mathrm{~d}$ of aging. The cheeses were also shredded at 3 different temperatures $\left(4,13\right.$, and $\left.22^{\circ} \mathrm{C}\right)$. Data were analyzed according to a factorial split-split plot 
design, with aging time and shredding temperature in the subplots and sub-subplots, respectively.

Melting Experiment. The cheese melting profiles were monitored at 8 and $36 \mathrm{~d}$ of aging. The softening point of the cheeses was analyzed according to a factorial split-split plot design, with aging time and premelting treatment in the subplots and sub-subplots, respectively.

Statistical Analysis. Analysis of variance was performed on the data using SAS software with PROC MIXED (version 2.0.3, 2008; SAS Institute Inc., Cary, $\mathrm{NC}$ ). Error bars on the figures represent the standard errors of the mean.

\section{RESULTS AND DISCUSSION}

\section{Cheese Composition}

The effect of denatured WP addition and renneting $\mathrm{pH}$ on cheese composition at $\mathrm{d} 1$ is summarized in Table 1. The $\mathrm{pH}$ and the salt:moisture ratio were similar among the cheeses $(P>0.05)$. As expected, the addition of WP to milk increased the moisture content of cheeses by about $2.4 \%$. Denatured WP aggregates are known to bind water effectively and may have detrimental effects on whey drainage, thus increasing water retention in cheese (Hinrichs, 2001). Protein and fat content was inversely related to moisture. The addition of WP significantly increased the protein retention in the cheeses. This result indicates that the denatured WP that were added were effectively retained in the cheese matrix.
Important physiochemical and biochemical changes occurred in the cheeses during the aging period (Table 2 ). The addition of WP did not significantly affect the WSN/TN\% $(P=0.08)$ or $\mathrm{CC}$ content $(P=0.45)$, but the renneting $\mathrm{pH}$ had a significant effect on those descriptors $(P=0.02$ and $P=0.04$, respectively). Figure 1 presents the evolution of CC and WSN/TN\% during aging as affected by renneting $\mathrm{pH}$. Colloidal calcium content was higher when milk was renneted at $\mathrm{pH} 6.5$ and remained higher during the aging period. Modifying the renneting $\mathrm{pH}$ is an efficient approach to control the mineralization of the cheese without changing its final pH (Johnson and Lucey, 2006; Choi et al., 2008). Insoluble calcium, linked to the caseins, is known to dissociate as milk $\mathrm{pH}$ decreases. Acidification before renneting allows better solubilization of calcium compared with after renneting because soluble calcium diffuses faster in a liquid than in a gel. As a result, more calcium is removed at drainage when the renneting $\mathrm{pH}$ is reduced. It should, however, be recognized that in the present study the drainage $\mathrm{pH}$ was reduced for cheeses renneted at lower $\mathrm{pH}$ and the effect of renneting $\mathrm{pH}$ cannot be separated from the effect of drainage $\mathrm{pH}$. The CC content slightly decreased in the early stage of storage but stabilized after $22 \mathrm{~d}$ of aging. Solubilization of CC during cheese aging was reported by other researchers (Lucey et al., 2005; O'Mahony et al., 2005), and these changes are known to be of primary importance for the rehydration of the paracasein matrix and textural changes in cheese during the first $10 \mathrm{~d}$ or so after manufacturing (McMahon et al., 1999; Johnson and Lucey, 2006).

Table 1. Means, $F$-values, and $P$-values for the analysis of the effect of denatured whey protein $(\mathrm{WP})$ addition and renneting $\mathrm{pH}$ on cheese composition

\begin{tabular}{|c|c|c|c|c|c|c|c|c|}
\hline \multirow[b]{2}{*}{ Item } & \multicolumn{4}{|c|}{ Mean of treatment ${ }^{1}$} & \multirow[b]{2}{*}{ SEM } & \multicolumn{3}{|c|}{ Factor effect ${ }^{2}[F$-value $(P$-value $)]$} \\
\hline & $\mathrm{R} 6.4$ & $\mathrm{R} 6.5$ & $\mathrm{R} 6.4$ & $\mathrm{R} 6.5$ & & WP & $\mathrm{RpH}$ & $\mathrm{WP} \times \mathrm{RpH}$ \\
\hline \multicolumn{9}{|l|}{ Composition } \\
\hline Moisture (\%) & 45.26 & 44.23 & 47.52 & 46.78 & 0.44 & $28.01 *(<0.01)$ & $3.23(0.11)$ & $0.01(0.92)$ \\
\hline Protein (\%) & 25.78 & 26.79 & 25.15 & 25.23 & 0.21 & $28.39 *(<0.01)$ & $7.19 *(0.03)$ & $6.17(0.06)$ \\
\hline Salt/moisture (\%) & 2.22 & 1.99 & 2.28 & 2.38 & 0.11 & $3.47(0.10)$ & $0.26(0.62)$ & $1.97(0.20)$ \\
\hline $\mathrm{pH}$ & 5.28 & 5.29 & 5.30 & 5.31 & 0.06 & $0.09(0.77)$ & $0.04(0.85)$ & $0.00(0.97)$ \\
\hline \multicolumn{9}{|l|}{ Retention coefficient } \\
\hline Protein $(\%)$ & 76.91 & 77.45 & 77.65 & 77.68 & 0.19 & $8.08^{*}(0.03)$ & $3.04(0.13)$ & $1.23(0.31)$ \\
\hline Fat $(\%)$ & 87.81 & 89.92 & 89.30 & 89.76 & 0.87 & $0.59(0.47)$ & $2.20(0.19)$ & $0.93(0.87)$ \\
\hline
\end{tabular}

${ }^{1}$ Means of the 4 main treatments: with $(0.25 \% \mathrm{WP})$ and without $(0 \% \mathrm{WP})$ denatured $\mathrm{WP}$ added to cheese milk renneted at $\mathrm{pH}=6.4$ or 6.5 (R6.4 and R6.5, respectively).

${ }^{2} F$-values and $P$-values (in parentheses) of the effect of WP addition, renneting $\mathrm{pH}(\mathrm{RpH})$, and the interaction effect $(\mathrm{WP} \times \mathrm{RpH})$ on the composition of cheese.

$* P<0.05$. 


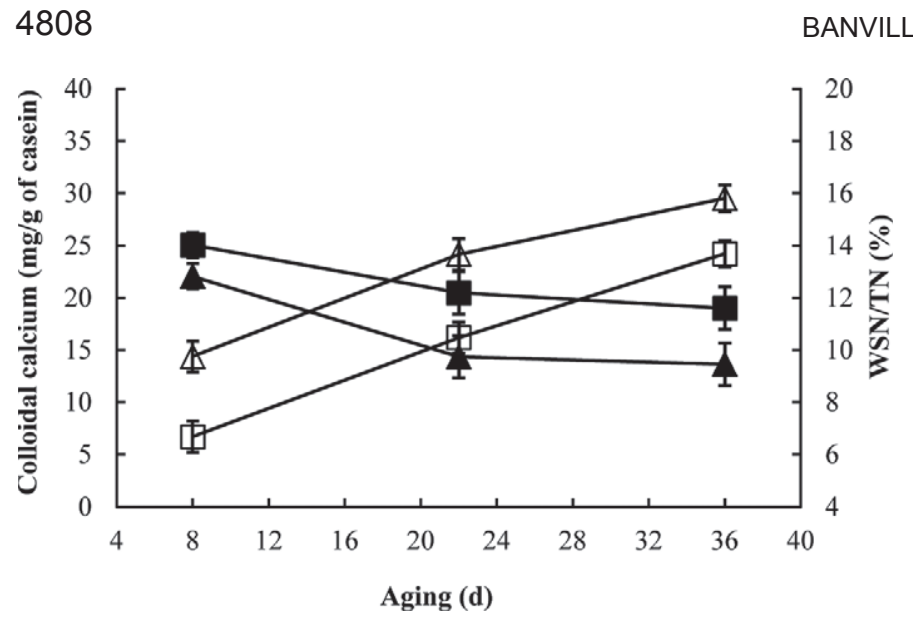

Figure 1. Effect of aging on colloidal calcium content (filled symbols) and the proportion of water-soluble nitrogen to total nitrogen (WSN/TN; open symbols) in pizza Mozzarella cheeses made with milk renneted at $\mathrm{pH}$ values of $6.4(\boldsymbol{\Delta})$ or $6.5(\boldsymbol{\square})$. Error bars represent SEM.

The analysis of the WSN/TN\% revealed important residual proteolytic activity in the cheeses during aging $(P<0.01)$, possibly from active coagulant enzyme, which resisted heat treatment during the cooking/ stretching process (Costabel et al., 2007). During aging, a higher WSN/TN\% value was consistently observed for the cheeses made from milk renneted at $\mathrm{pH} 6.4 \mathrm{com}-$ pared with 6.5 (Figure 1). As demonstrated by other researchers, a low CC content in cheese also promotes a lower degree of casein aggregation, which facilitates the accessibility of proteolytic enzymes that eventually release free $\alpha$ - and $\beta$-CN from the paracasein matrix (Feeney et al., 2002; Zisu and Shah, 2005).

\section{Shredding Experiment}

Size Distribution of Shredded Cheese Fractions. A close examination of the partition between the 4 shred fractions showed that the percentage of fines (size $<4.00 \mathrm{~mm}^{2}$ ) produced during shredding was positively correlated to the percentage of small shreds $\left(4.00 \mathrm{~mm}^{2}<\right.$ size $\left.<11.22 \mathrm{~mm}^{2}\right)$, at a coefficient of determination of 0.72 . Therefore, the percentage of fines and long shreds obtained from the shredding experiment are further examined.

Fines Production. The effect of factors influencing the fines production of cheeses is summarized in Table 3 . Although the effect of aging on fines production seemed to be a dominant factor, the effect varied with renneting $\mathrm{pH}$ during cheese making and WP concentration $(P<0.01)$. The proportion of fines produced during the cheese-shredding operation is presented in Figure 2. For the cheeses without WP, lowering the renneting $\mathrm{pH}$ to 6.4 and aging the cheese systematically decreased the fines production during shredding. The effect of aging and the renneting $\mathrm{pH}$ probably influenced the mechanical properties of the paracasein matrix. Young Mozzarella cheese typically has a dehydrated, relatively rigid and fibrous protein structure surrounded by channels of free water and fat (Auty et al., 1999; McMahon et al., 1999). These characteristics could be responsible for cheese brittleness and partly explain the high proportion of fines produced when Mozzarella cheese is shredded (Childs et al., 2007). As reported by Gunasekaran and Ak (2002), the fracture mechanism of cheese is closely related to its microstructure and, more importantly, to the protein phase and the homogeneity of the cheese. Under sufficient stress, a rigid protein matrix is expected to fracture more cleanly. At the opposite end of the spectrum, fewer and weaker bonds holding the casein matrix together allow faster rearrangement of the cheese microstructure and better adaptation to deformation (Masi and Addeo, 1986; Watkinson et al., 2001). Heterogeneity in cheese structure can also

Table 2. $F$-values and $P$-values (in parentheses) for the analysis of the effect of denatured whey protein (WP) addition and renneting $\mathrm{pH}$ on cheese colloidal calcium and water-soluble nitrogen as a percentage of total nitrogen (WSN/TN\%) during aging

\begin{tabular}{|c|c|c|c|}
\hline \multirow[b]{2}{*}{ Factor $^{1}$} & \multirow[b]{2}{*}{ df } & \multicolumn{2}{|c|}{$F$-value $(P$-value $)$} \\
\hline & & Colloidal calcium & WSN/TN\% \\
\hline \multicolumn{4}{|l|}{ Whole plot } \\
\hline WP & 1 & $0.67(0.45)$ & $4.47(0.08)$ \\
\hline $\mathrm{RpH}$ & 1 & $6.64 *(0.04)$ & $10.11 *(0.02)$ \\
\hline $\mathrm{WP} \times \mathrm{RpH}$ & 1 & $0.08(0.79)$ & $0.00(0.95)$ \\
\hline Error & 8 & & \\
\hline \multicolumn{4}{|l|}{ Subplot } \\
\hline A & 2 & $7.62 *(0.01)$ & $37.40 *(<0.01)$ \\
\hline $\mathrm{A} \times \mathrm{WP}$ & 2 & $0.10(0.90)$ & $0.88(0.44)$ \\
\hline $\mathrm{A} \times \mathrm{RpH}$ & 2 & $0.59(0.57)$ & $0.42(0.67)$ \\
\hline $\mathrm{A} \times \mathrm{WP} \times \mathrm{RpH}$ & 2 & $1.38(0.29)$ & $0.26(0.77)$ \\
\hline Error & 16 & & \\
\hline
\end{tabular}

${ }^{1}$ Split-plot design with the WP addition and the renneting $\mathrm{pH}(\mathrm{RpH})$ as a factorial $2 \times 2$ main plot. Subplot included the effect of aging of cheese (A).

$* P<0.05$. 
promote microcrack formation because heterogeneity causes an unequal distribution of the stress applied to the matrix (Gunasekaran and Ak, 2002). The protein elongation during the stretching of pasta filata is recognized as promoting the distinctive segregation of protein, lipid, and aqueous phases, which is especially noticeable in young cheeses (Auty et al., 1999; Everett and Auty, 2008). Strong casein interactions, via CC cross-linking, also contribute to the matrix heterogeneity, probably through water expulsion from the protein fibers (McMahon et al., 2005). As the cheese ages, however, the paracasein matrix progressively absorbs the free serum trapped in the interprotein channels. Microscopic experiments showed that the fibrous protein structures eventually disappear during aging and the cheese matrix becomes more homogeneous (Auty et al., 1999; McMahon et al., 1999; Kuo and Gunasekaran, 2009). In addition to the solubilization of CC, the proteolysis of caseins during cold storage also contributes to protein hydration (Kindstedt and Guo, 1997; Joshi et al., 2004; McMahon et al., 2005; Cortez et al., 2008).

Figure 2 also shows that adding WP to the cheese formulation increased fines production for short aging periods. However, fines production was dramatically reduced during aging, and this effect became more im-

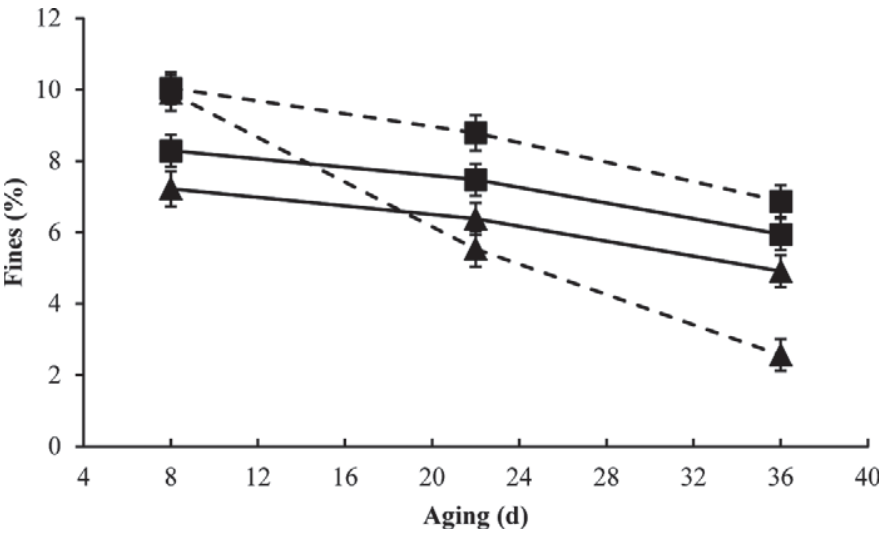

Figure 2. Effect of aging on the percentage of fines measured after the shredding of Mozzarella cheeses made from milk with $(0.25 \% \mathrm{WP}$; dashed lines) or without ( $0 \% \mathrm{WP}$; solid lines) denatured whey protein $(\mathrm{WP})$ and renneted at $\mathrm{pH}$ values of $6.4(\boldsymbol{\Lambda})$ or $6.5(\boldsymbol{\square})$. Error bars represent SEM.

portant when the renneting $\mathrm{pH}$ was reduced. Fines production from the cheeses with WP (renneting $\mathrm{pH}$ 6.4) was reduced by a factor of 4.5 between 8 and $36 \mathrm{~d}$ of storage. In comparison, for the cheeses without WP, fines production was reduced only by a factor of 1.7 over the same aging period. The effect of WP addition

Table 3. $F$-values and $P$-values (in parentheses) for the analysis of the effect of denatured whey protein (WP) addition, renneting pH, aging, and temperature on cheese shredding properties

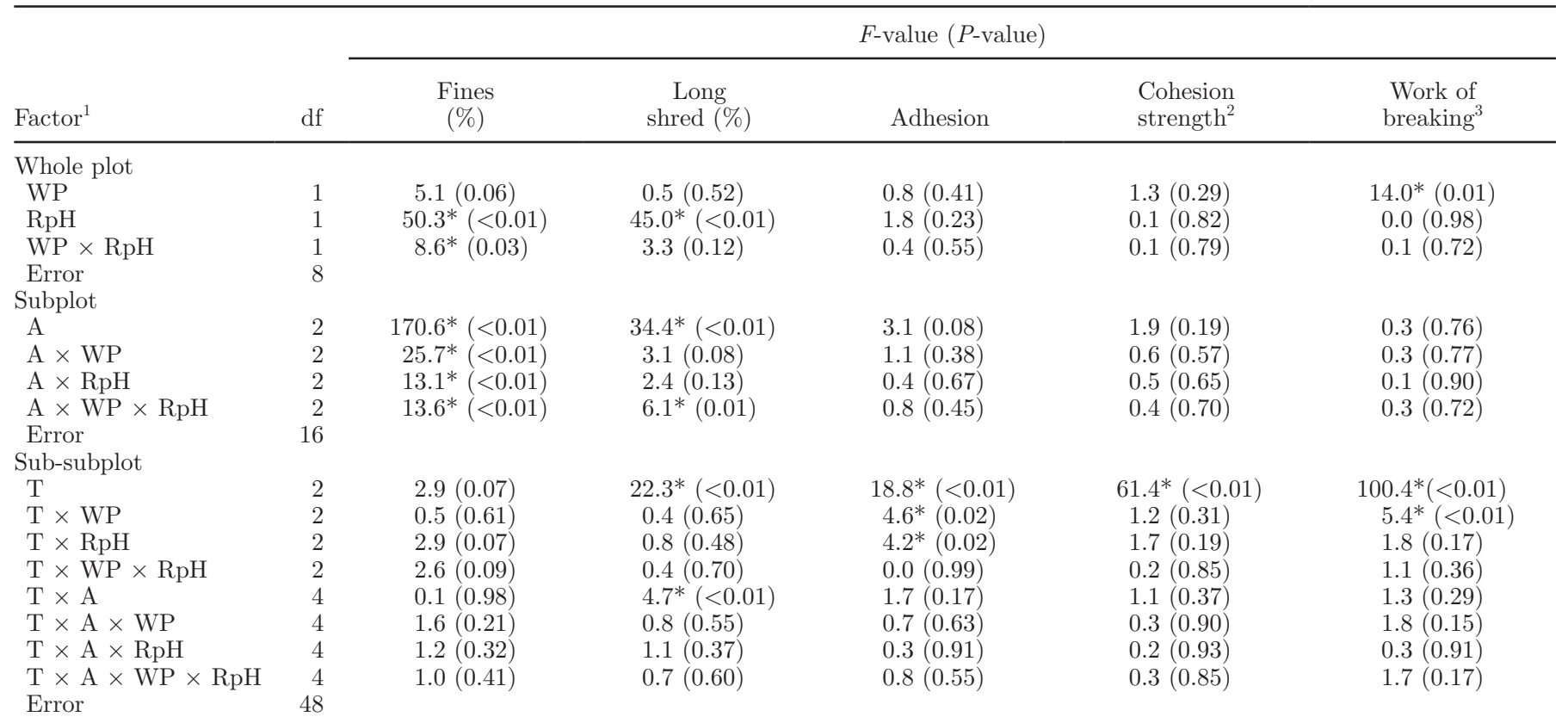

\footnotetext{
${ }^{1}$ Split-split-plot design with the denatured WP addition and the renneting $\mathrm{pH}(\mathrm{RpH})$ as a factorial $2 \times 2$ main plot. Subplot included the effect of aging of cheese (A), and sub-subplot accounted for the effect of the shredding temperature (T).

${ }^{2}$ The cohesion strength corresponds to the initial force required to penetrate the cake and depends on the closeness of the shreds and their ability to form strong links (i.e., interactions between shreds).

${ }^{3}$ The work of breaking represents the force required to perform the matting test, before the point where all cakes fractured.

$* P<0.05$.
} 
on the properties of part-skim Mozzarella cheese is not fully understood.

Some authors have suggested that WP aggregates act as inert fillers that might disrupt the paracasein matrix of cheese (Steffl et al., 1999; Schenkel et al., 2011;). The inclusion of WP would then induce weak spots in the matrix of young cheese. Fenelon and Guinee (1997) reported that a cheese made with commercial WP (DairyLo) was more crumbly than a control cheese. Mead and Roupas (2001) noticed that the addition of WP resulted in a more fibrous Mozzarella cheese with poor functional characteristics compared with a WP-free control cheese after the same aging period. As aging occurs, the hydration and proteolysis of the cheese paracasein matrix facilitate the inclusion of WP aggregates into a reorganized and more homogeneous matrix. A low renneting $\mathrm{pH}$ during cheese making would increase this effect because it has been shown to promote proteolysis (Figure 1). Lelièvre (1995) also suggested that a disrupted casein network, induced by lowering cheese $\mathrm{pH}$, improved the integration of WP aggregates into the cheese matrix with minimal effect on microstructure. A low CC content in cheese promoted by reducing the $\mathrm{pH}$ at renneting or drainage, or both, is expected to decrease casein interactions, thus loosening the protein matrix. The cheese temperature at shredding had no significant effect on fines production $(P=0.07)$, and no particular trend could be attributed to this factor. This is surprising considering that temperature has a wellknown effect on cheese texture (Gunasekaran and $\mathrm{Ak}$, 2002). Childs et al. (2007) reported an increase of about $71 \%$ in fines production when the shredding temperature of Mozzarella cheese increased from 12 to $20^{\circ} \mathrm{C}$. Those authors suggested that the softening of cheeses observed at higher temperatures caused more fines, but no explanation was provided. The low dependency observed between the fines production and the cheese temperature in our shredding experiment supports the hypothesis that the protein microstructure (through its fibrous arrangement) is the primary factor involved in the shattering of Mozzarella cheese into fines.

Long-Shred Production. The effect of factors influencing the long-shred production during shredding is presented in Table 3. Contrarily to WP addition, the renneting $\mathrm{pH}$ significantly affected the proportion of long shreds. Reducing renneting $\mathrm{pH}$ from 6.5 to 6.4 increased the proportion of long shreds from $45 \pm 1$ to $55 \pm 1 \%$ (data not shown). The production of long shreds also varied with the cheese aging time and the shredding temperature $(P<0.01)$. Figure 3 presents the interaction effect of aging and shredding temperature on long-shred production. When shredding at $4^{\circ} \mathrm{C}$, the proportion of long shreds was reduced with increasing cheese aging time. For cheeses aged 8 or $22 \mathrm{~d}$, the

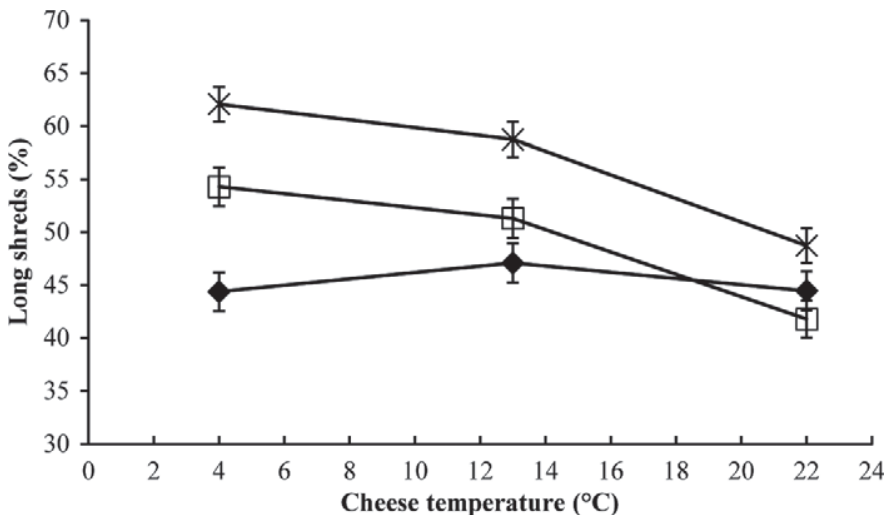

Figure 3. Effect of cheese temperature during shredding on the percentage of long shreds in pizza Mozzarella cheeses aged for $8(\times)$, $22(\square)$, or $36 \mathrm{~d}(\bullet)$. Error bars represent SEM.

proportion of long shreds was shown to decrease with increasing shredding temperature, whereas for cheese aged for $36 \mathrm{~d}$, the shredding temperature had no effect on the proportion of long shreds.

Chen (2003) evaluated shredded Mozzarella cheese using a sensory panel and found that shred preferences and quality were related to the length $(60 \%)$, thickness $(20 \%)$, and straightness (20\%) of shreds. The same author reported that firmness, measured by torsion stress rheometry, was the best analytical descriptor that correlated with shred preferences. Therefore, it seems that a high proportion of long shreds is desirable when shredding Mozzarella cheese. Given that the firmness of cheese decreases with rising temperature and increasing aging time (Gunasekaran and Ak, 2002), our results suggest that a firmer cheese would generally produce a larger amount of long shreds. This observation is in agreement with the assumption that firm cheeses produce shreds with better characteristics (Kindstedt, 1995; Chen, 2003; Childs et al., 2007). However, the temperature had no effect on long-shred production in older cheeses (36 d). Apparently, the appropriate microstructure for shredding cannot be restored by decreasing the shredding temperature for older cheeses.

Adhesion of Cheese to Shredding Blade. The effect of factors influencing the adhesion of cheese to the blade is presented in Table 3. Aging the cheeses did not significantly affect the adhesion of cheese residue to the blade $(P=0.08)$. However, the trend indicates that aging increased cheese adhesion. An average difference of $18 \%$ was observed between the cheeses stored for 8 and $36 \mathrm{~d}$ in terms of the weights of residue adhering to the blade (data not shown). Childs et al. (2007) obtained similar results between Mozzarella cheeses aged for 7 and $28 \mathrm{~d}$. The increased gumminess reported by Kindstedt (1995) in Mozzarella cheeses after 2 to $3 \mathrm{wk}$ of storage could not be clearly seen in the current study, 
probably because of variations in the method used for measuring adhesion to the blade. The cheeses may also have required, under the manufacturing conditions used in the current study, further aging to develop the gumminess reported by that author.

The temperature of cheese during shredding was the main factor influencing adhesion, but this effect was dependent on the presence of denatured WP in cheese milk and renneting $\mathrm{pH}$ (Table 3). As shown in Figure 4, the weight of cheese residue was relatively low and constant at 4 and $13^{\circ} \mathrm{C}$ but increased when the cheese was shredded at $22^{\circ} \mathrm{C}$. According to visual observations, the residue appeared as small and definite particles when the cheese was shredded at 4 or $13^{\circ} \mathrm{C}$. When the cheese was shredded at room temperature $\left(22^{\circ} \mathrm{C}\right)$, however, a spread of cheese was visible on the blade. A lower renneting $\mathrm{pH}$ and the addition of denatured WP further increased the adhesion of the cheese shredded at $22^{\circ} \mathrm{C}$. A decrease in protein cross-linking caused by the solubilization of CC and a high moisture content are among the factors that promote soft and spreadable cheese (Marchesseau et al., 1997; Dimitreli and Thomareis, 2008).

Matting Behavior of Shreds. A typical curve obtained from the matting test and the descriptors used for the characterization of the shred cakes are presented in Figure 5. The matting test was designed to simulate the matting behavior of shreds in industrial packaging. The textural descriptors were the cohesion strength and the work of breaking of the cake. The cohesion strength corresponds to the initial force required to penetrate the cake and depends on the closeness of the shreds and their ability to form strong links (i.e., interactions

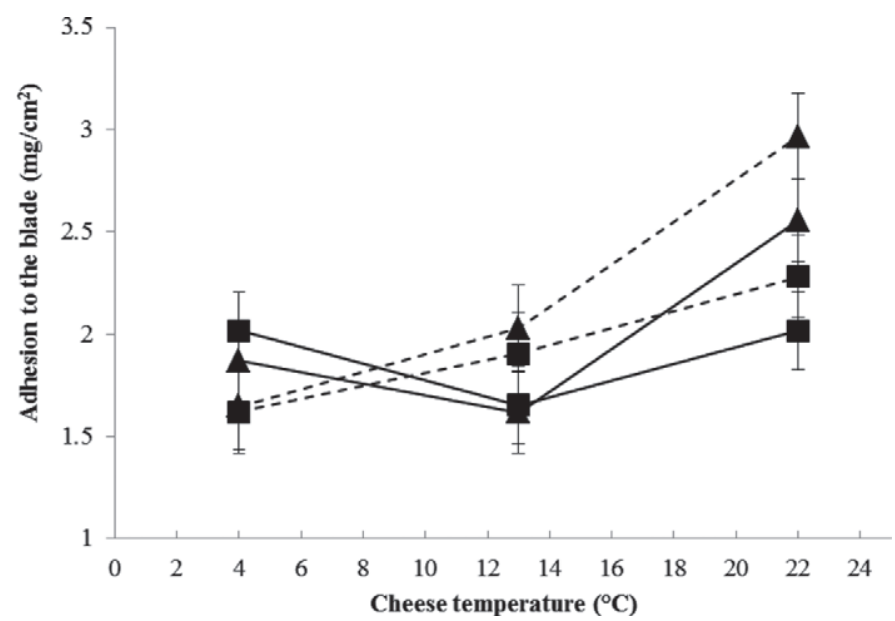

Figure 4. Effect of cheese temperature during shredding on the adhesion to the blade of pizza Mozzarella cheeses made from milk with (0.25\% WP; dashed lines) or without (0\% WP; solid lines) denatured whey protein (WP) and renneted at $\mathrm{pH}$ values of $6.4(\boldsymbol{\Delta})$ or $6.5(\mathbf{\square})$. Error bars represent SEM.

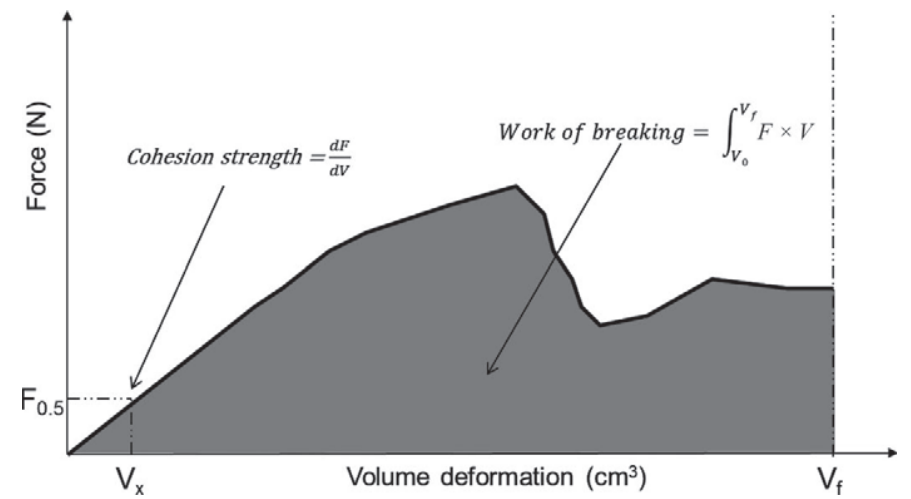

Figure 5. Typical curve of force (F) versus volume deformation (V) of a cheese shred cake during the matting experiment. The cohesion strength is the initial slope of the curve measured at $0.5 \mathrm{~N}$. The work of breaking is the force required to perform the test.

between shreds). The work of breaking represents the force required to perform the matting test, before the point where all cakes fractured. Low work of breaking is a desirable attribute because it reflects the ease of separating the mat of shreds into individual identities, which facilitates shred handling and distribution (Kindstedt, 1995).

The result of the matting test was best represented as a texture map reporting the work of breaking plotted against the cohesion strength of the shred cakes (Figure $6)$. The $F$ - and $P$-values associated with factors influencing the cohesion strength and the work of breaking are presented in Table 3. The cohesion strength varied with the temperature of the shreds at cake preparation $(P<0.01)$. As the temperature increased, the cohesion strength increased significantly (Figure 6). The softening of shreds at high temperatures promoted a higher compaction during cake formation. Moreover, the partial melting of fat at higher temperatures released free fat on the shred surfaces that solidified during cooling and increased the overall cohesion strength of the cakes. The work of breaking of the cakes also increased with the temperature but varied with the WP concentration in the cheeses $(P<0.01)$. The cakes prepared at room temperature $\left(22^{\circ} \mathrm{C}\right)$ fractured into big clumps but required a great amount of force to reach the fracture point. In comparison, the shred cakes prepared at $4^{\circ} \mathrm{C}$ were puffy and light and fell apart easily. The addition of WP to the cheeses decreased the work of breaking by 15 and $22 \%$ for the cakes prepared at 13 and $22^{\circ} \mathrm{C}$, respectively. No effect of WP was detected at the lowest temperature $\left(4^{\circ} \mathrm{C}\right)$. The cause of this phenomenon is not clear, but a hypothetical explanation could be that the higher moisture content of the cheeses that contained WP had a lubricating effect on the shred surfaces and, thus, increased the breaking properties of the cakes. 


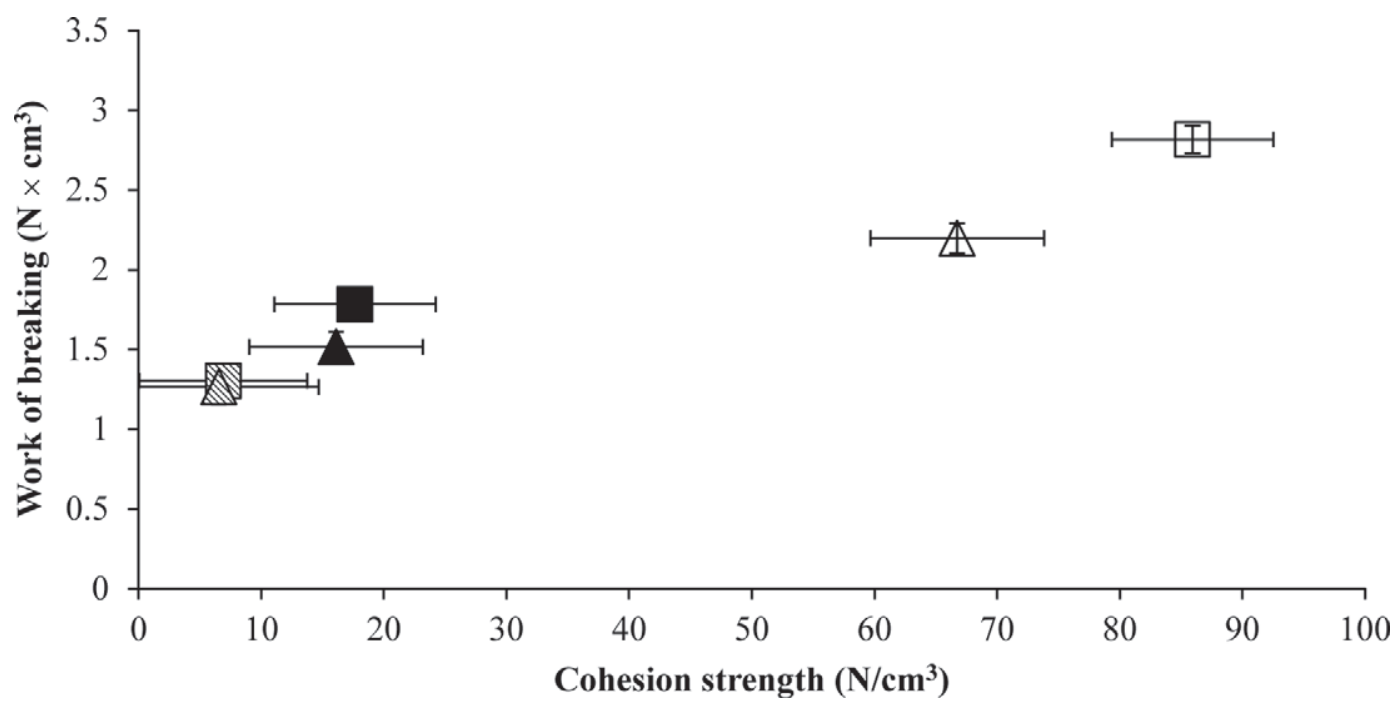

Figure 6. Matting behavior of the pizza Mozzarella cheese shred cakes represented by the cohesion strength and the work of breaking. Results are presented for cheese made from milk with $(0.25 \% \mathrm{WP} ; \mathbf{\Delta})$ or without $(0 \% \mathrm{WP}$; $)$ denatured whey protein (WP). The temperature during cake preparation was 4 (hatched symbols), 13 (filled symbols), or $22^{\circ} \mathrm{C}$ (open symbols). All cakes were tested at $4^{\circ} \mathrm{C}$. Error bars represent SEM.

\section{Melting Experiment}

The melting profiles were obtained from the rheological experiment by measuring the $\mathrm{G}^{*}$ and the $\delta$ as a function of temperature. The melting profiles were pooled and presented as the means of the effect of the principal factors: denatured WP concentration in milk, renneting $\mathrm{pH}$, aging, and premelting treatment (Figure 7). As expected, increasing temperature systematically decreased $\mathrm{G}^{*}$ and increased $\delta$. The dynamic moduli are generally good indicators of the number and strength of the bonds holding the cheese matrix together (Lucey et al., 2003). The melting of cheese is a continuous process, leading to a more liquid-like (higher $\delta$ ) and weaker (lower $\mathrm{G}^{*}$ ) material (Gunasekaran and Ak, 2002). It is generally accepted that 2 concomitant physical changes contribute to the melting of cheese: (1) the progressive liquefaction of the milk fat and (2) the reinforcement of hydrophobic bonds, which has a contracting effect on individual molecules and, thus, globally reduces the contact area between the proteins forming the cheese matrix as the temperature increases (Lucey et al., 2003; Johnson and Lucey, 2006; Guggisberg et al., 2007).

Effect of WP. As it would be expected, the $\mathrm{G}^{*}$ measured at $5^{\circ} \mathrm{C}$ was slightly lower for the cheeses with WP, but this difference was not significant. Indeed, no effect of the addition of WP to cheese on the melting profiles could be detected for temperatures under $60^{\circ} \mathrm{C}$ (Figure 7A). Despite the higher moisture of cheeses with WP, their protein-to-DM ratio and fat content, 2 major compositional factors affecting meltability (Johnson and Lucey, 2006), were similar to cheeses without WP. However, a lower $\delta\left(\right.$ at $>60^{\circ} \mathrm{C}$ ) and a slightly higher $\mathrm{G}^{*}\left(\right.$ at $>80^{\circ} \mathrm{C}$ ) were measured on the cheeses supplemented with WP. It has been shown that the $\delta$ values measured under melting temperatures were lower with increasing WP aggregate concentrations in cheese (Schenkel et al., 2011). As previously mentioned, the contraction of casein particles at high temperatures contributes to the melting of cheese. Whey protein particles are highly cross-linked through intermolecular disulfide bonds, limiting the capacity of those particles to reorganize and contract at high temperatures, which may explain the reduced melting performance of the cheeses containing WP. Lelièvre (1995) also suggested that whey protein aggregates complex to caseins and that the polymer chains formed could impair cheese meltability.

Effect of Renneting $\boldsymbol{p H}$. Modifying the renneting $\mathrm{pH}$ of milk affected the melting profiles of the cheeses (Figure $7 \mathrm{~B})$. At low temperatures $\left(5-30^{\circ} \mathrm{C}\right)$, the $\mathrm{G}^{*}$ of the cheeses made with milk renneted at $\mathrm{pH} 6.4$ was slightly lower than those made with milk renneted at 6.5. The same trend was observed for temperatures at which milk fat in cheese is expected to be in the liquid state $\left(>40^{\circ} \mathrm{C}\right.$; Vithanage et al., 2009). It is likely that the strength and number of cross-linkages between the caseins forming the cheese network influenced the physical properties of the cheeses, as reflected by the complex modulus (Gunasekaran and Ak, 2002). O’Mahony et al. (2006) demonstrated that the storage and loss moduli of melted cheeses decreased with decreasing concentration of CC. Therefore, the results from Figure 7B were expected, considering the effect of the renneting $\mathrm{pH}$ on both the CC content and proteolysis in the cheeses (Figure 1). For temperatures ranging from 40 to $60^{\circ} \mathrm{C}$, 

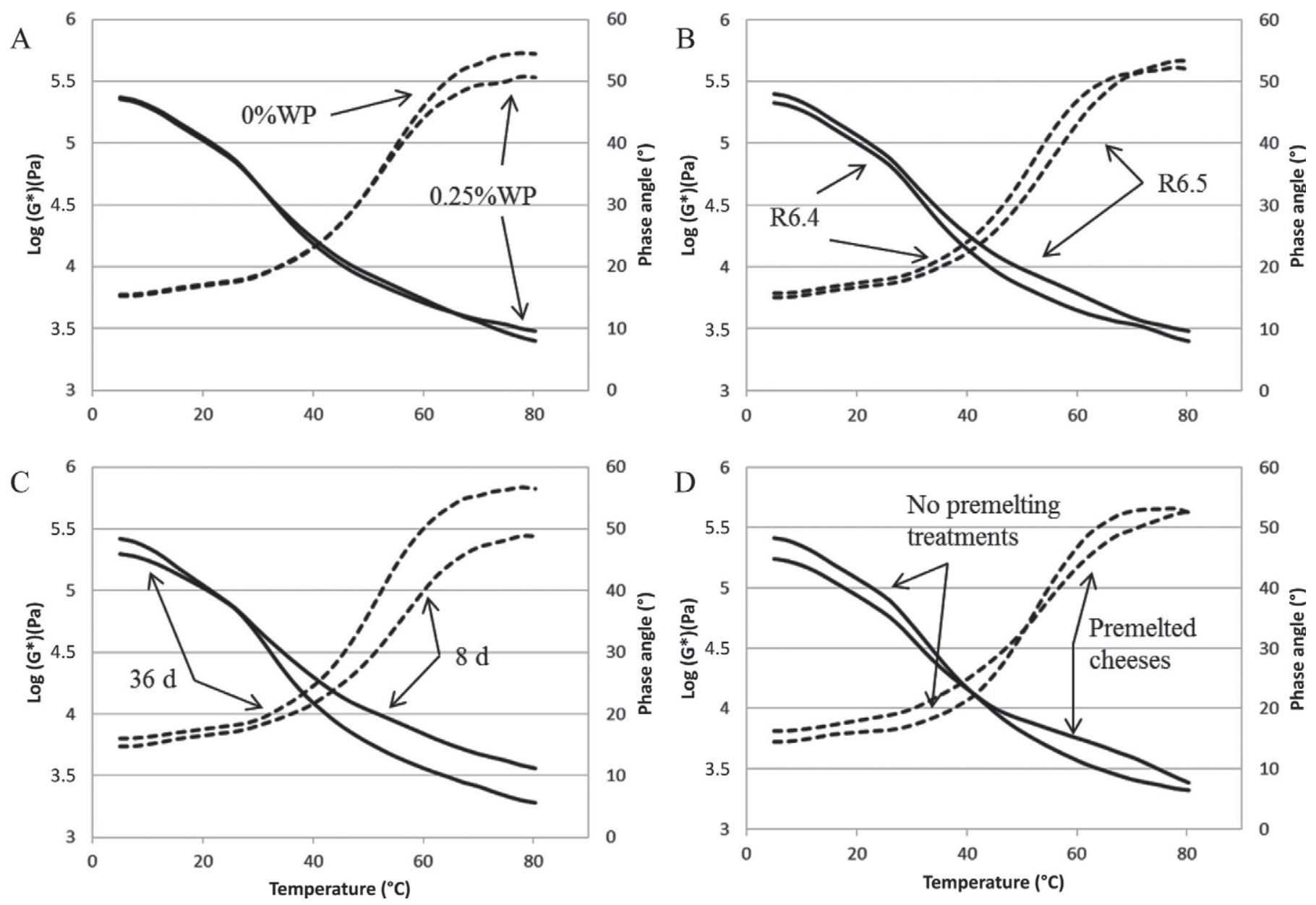

Figure 7. Effect of denatured whey protein (WP) in milk (A), renneting $\mathrm{pH}(\mathrm{R} ; \mathrm{B})$, cheese aging (C), and premelting treatment (D) on the melting profiles of pizza Mozzarella cheeses assessed by the complex modulus ( $\mathrm{G}^{*}$; solid lines) and the phase angle $(\delta$; dashed lines).

higher $\delta$ values were observed for the cheeses renneted at $\mathrm{pH} 6.4$ compared with those renneted at 6.5. Higher $\delta$ values are associated with a more liquid-like behavior under mechanical deformation at high temperatures, which improves flow properties during melting.

Effect of Aging. The aged cheeses (36 d) showed a lower $\mathrm{G}^{*}$ and a higher $\delta$ compared with the young cheeses $(8 \mathrm{~d})$ for all the temperatures tested (Figure $7 \mathrm{C})$. This result is in keeping with the general agreement that cheeses develop better melting properties as they age. Numerous studies showed that the proteolysis of caseins and the loss of CC, both of which occur during refrigerated aging, are primary factors that improve cheese meltability (Kindstedt, 1993; Joshi et al., 2004; Choi et al., 2008).

Effect of Premelting Treatment. The melting profiles of the cheeses were affected by a premelting treatment before testing (Figure 7D). The premelted cheeses were softer (lower $\mathrm{G}^{*}$ ) and less elastic (higher $\delta)$ at lower temperatures $\left(<40^{\circ} \mathrm{C}\right)$ than the cheeses that had not undergone the premelting treatment. Interestingly, the opposite trend was observed for temperatures above $50^{\circ} \mathrm{C}$. Premelting the cheese modified its physical properties and rheological behavior depending on the temperature. Monitoring and understanding the changes induced by the baking of cheese could help to better control the desirable physical attributes of cooled or reheated cheese-topped dishes. Under classic baking conditions, moisture and fat losses explain most of the textural changes in cheese after solidification (Gunasekaran and Ak, 2002; Kim et al., 2011). In the present study, the premelting treatment was applied in a closed environment, and the composition of the cheeses was unchanged. The higher $\mathrm{G}^{*}$ observed above $50^{\circ} \mathrm{C}$ for the premelted cheese is probably associated with a reinforcement of the protein matrix, given that the contribution of milk fat to the $\mathrm{G}^{*}$ above $40^{\circ} \mathrm{C}$ is assumed to be minimal (Vithanage et al., 2009; Yang et al., 2011). Some studies previously suggested that protein interactions, perhaps through calcium bonding, 
play a role in the physical properties of melted and post-melted cheeses (Metzger et al., 2001; Pastorino et al., 2002; Kim et al., 2011). In agreement with our study, Kuo et al. (2001) also measured variations in the meltability of Mozzarella cheeses with different heating histories. Changes in fat distribution during premelting could possibly explain the lower $\mathrm{G}^{*}$ and higher $\delta$ in those cheeses below $40^{\circ} \mathrm{C}$. Previous studies reported the formation of large fat pools during the baking of Mozzarella cheeses, driven by the reorganization of the protein matrix (Kindstedt, 1993; Auty et al., 1999). According to Laplace's pressure theory, increasing fat globule size for a constant volume fraction reduces the contribution of lipids to cheese firmness (Everett and Auty, 2008).

Softening Point. The softening point temperature of cheese represents the transition phase where the dissipated mechanical energy is equal to the energy stored in the cheese structure (Gunasekaran and Ak, 2002). An increase in the softening point temperature has been negatively correlated with cheese meltability as measured by empirical tests (Stenz et al., 2006; Ko and Gunasekaran, 2008). The renneting $\mathrm{pH}$ and WP conditions did not significantly affect the softening point temperature of the cheeses. However, the average softening point temperature decreased from 66 to $57^{\circ} \mathrm{C}$ for the cheeses aged 8 and $36 \mathrm{~d}(P<0.01)$. Increased proteolysis and decreased CC concentration are among the factors known to be responsible for meltability improvement (Kindstedt et al., 1995). Both factors were observed during the aging of the Mozzarella cheeses (Figure 1). Premelting of the cheeses significantly increased the average softening point temperature by $3^{\circ} \mathrm{C}$ $(P<0.01)$, thus confirming that cheese meltability was impaired by heat-induced changes.

\section{CONCLUSIONS}

The aging of pizza Mozzarella cheeses that were manufactured from milk with or without denatured $\mathrm{WP}$ and renneted at 2 different $\mathrm{pH}$ values resulted in products that varied in terms of their moisture, CC, and soluble-nitrogen contents. These manufacturing conditions also generated major effects on the physical properties of both the unmelted and melted cheeses. A low milk renneting $\mathrm{pH}$ and cheese aging can effectively decrease fines production during shredding. Moreover, our results show that controlling these 2 manufacturing conditions is essential when denatured WP is included in cheese milk formulations. In contrast, when the cheeses were aged, the proportion of long shreds was lower, thus affecting overall shreddability. To reduce the adhesion of the cheese to the blade and to maximize the shred size, pizza Mozzarella cheese should be shredded at low temperatures. In addition, shredded cheese should also be packaged and stored at low temperatures to reduce defects associated with the matting of shreds. The renneting $\mathrm{pH}$ of milk and the aging of cheese should also be controlled to produce pizza Mozzarella cheese with desirable melting properties. In addition, the physical properties of cheeses that had been premelted were investigated. A freshly baked pizza topped with Mozzarella cheese can be eaten right away or reheated the next day, and the cheese is expected to perform well in both conditions. This work demonstrates that the premelting of cheese leads to important changes in its physical properties $\left(G^{*}\right.$ and $\left.\delta\right)$, probably through heatinduced microstructural rearrangements. Further studies will investigate the mechanism behind heat-induced textural, structural changes and its relationship with consumers' perceptions.

\section{ACKNOWLEDGMENTS}

This work was funded by the Natural Sciences and Engineering Research Council of Canada (NSERC; Ottawa, ON, Canada), the Fonds québecois de la recherche sur la nature et les technologies (FQRNT; Québec, QC, Canada), and Agropur Cooperative (Longueuil,, QC, Canada). The authors thank their colleagues at Agriculture and Agri-Food Canada (Saint-Hyacinthe, QC, Canada) and Agropur Cooperative for their scientific and technical expertise.

\section{REFERENCES}

Akbulut, C., S. Govindasamy-Lucey, J. A. Lucey, J. J. Jaeggi, and M. E. Johnson. 2011. Impact of grating size on the texture and melting properties of reformed non-fat cheese. Milchwissenschaft 66:169-172.

Apostolopoulos, C., and R. J. Marshall. 1994. A quantitative method for the determination of shreddability of cheese. J. Food Qual. $17: 115-158$.

Auty, M. A. E., M. A. Fenelon, T. P. Guinee, C. Mullins, and D. M. Mulvihill. 1999. Dynamic confocal scanning laser microscopy methods for studying milk protein gelation and cheese melting. Scanning 21:299-304.

Chen, C. 2003. Development and application of a cheese shred/texture map delineated by cheese rheological, sensory and chemical analysis. Annual Report. Wisconsin Center for Dairy Research, Madison.

Childs, J. L., C. R. Daubert, L. Stefanski, and E. A. Foegeding. 2007. Factors regulating cheese shreddability. J. Dairy Sci. 90:21632174. http://dx.doi.org/10.3168/jds.2006-618.

Choi, J., D. S. Horne, M. E. Johnson, and J. A. Lucey. 2008. Effects of the concentration of insoluble calcium phosphate associated with casein micelles on the functionality of directly acidified cheese. J. Dairy Sci. 91:513-522. http://dx.doi.org/10.3168/jds.2007-0454.

Cortez, M. A. S., M. M. Furtado, M. L. Gigante, and P. S. Kindstedt. 2008. Effect of $\mathrm{pH}$ on characteristics of low-moisture Mozzarella cheese during refrigerated storage. J. Food Sci. 73:S443-S448. http://dx.doi.org/10.1111/j.1750-3841.2008.00943.x.

Costabel, L., M. S. Pauletti, and E. Hynes. 2007. Proteolysis in Mozzarella cheeses manufactured by different industrial processes. J. Dairy Sci. 90:2103-2112. http://dx.doi.org/10.3168/jds.2006-795.

Dimitreli, G., and A. S. Thomareis. 2008. Effect of chemical composition on the linear viscoelastic properties of spreadable-type processed cheese. J. Food Eng. 84:368-374. 
Everett, D. W., and M. A. E. Auty. 2008. Cheese structure and current methods of analysis. Int. Dairy J. 18:759-773. http://dx.doi. org/10.1016/j.idairyj.2008.03.012.

Feeney, E. P., T. P. Guinee, and P. F. Fox. 2002. Effect of pH and calcium concentration on proteolysis in Mozzarella cheese. J. Dairy Sci. $85: 1646-1654$.

Fenelon, M. A., and T. P. Guinee. 1997. The compositional, textural and maturation characteristics of reduced-fat Cheddar made from milk containing added Dairy-Lo ${ }^{\mathrm{TM}}$. Milchwissenschaft 52:385-389.

Guggisberg, D., U. Bütikofer, and B. Albrecht. 2007. Melting and solidification characteristics of Swiss Raclette cheese measured by small amplitude oscillatory shear measurements. J. Texture Stud. 38:297-323.

Gunasekaran, S., and M. M. Ak. 2002. Cheese Rheology and Texture. CRC Press, Boca Raton, FL.

Hinrichs, J. 2001. Incorporation of whey proteins in cheese. Int. Dairy J. 11:495-503.

Ismail, M., E.-T. Ammar, and R. El-Metwally. 2011. Improvement of low fat Mozzarella cheese properties using denatured whey protein. Int. J. Dairy Technol. 64:207-217. http://dx.doi.org/10.111 1/j.1471-0307.2010.00654.

Johnson, M. E., and J. A. Lucey. 2006. Calcium: A key factor in controlling cheese functionality. Aust. J. Dairy Technol. 61:147-153.

Joshi, N. S., K. Muthukumarappan, and R. I. Dave. 2003. Understanding the role of calcium in functionality of part skim Mozzarella cheese. J. Dairy Sci. 86:1918-1926.

Joshi, N. S., K. Muthukumarappan, and R. I. Dave. 2004. Effect of calcium on microstructure and meltability of part skim Mozzarella cheese. J. Dairy Sci. 87:1975-1985.

Kim, S. Y., S. Lim, and S. Gunasekaran. 2011. Protein interactions in reduced-fat and full-fat Cheddar cheeses during melting. LWT Food Sci. Technol. 44:582-587. http://dx.doi.org/10.1016/j. lwt.2010.07.011.

Kindstedt, P. S. 1993. Effect of manufacturing factors, composition, and proteolysis on the functional characteristics of Mozzarella cheese. Crit. Rev. Food Sci. Nutr. 33:167-187.

Kindstedt, P. S. 1995. Factors affecting the functional characteristics of unmelted and melted Mozzarella cheese. Pages 27-41 in Chemistry of Structure-Function Relationships in Cheese. Advances in Experimental Medicine and Biology. Vol. 367. E. L. Malin and M. H. Tunick, ed. Plenum Press, New York, NY.

Kindstedt, P. S., and M. R. Guo. 1997. Recent developments in the science and technology of pizza cheese. Aust. J. Dairy Technol. $52: 41-43$.

Kindstedt, P. S., J. J. Yun, D. M. Barbano, and K. L. Larose. 1995. Mozzarella cheese: Impact of coagulant concentration on chemical composition, proteolysis, and functional properties. J. Dairy Sci. 78:2591-2597.

Ko, S., and S. Gunasekaran. 2008. Analysis of cheese melt profile using inverse-Hill function. J. Food Eng. 87:266-273. http://dx.doi. org/10.1016/j.jfoodeng.2007.12.002.

Kuo, M.-I., and S. Gunasekaran. 2009. Effect of freezing and frozen storage on microstructure of Mozzarella and pizza cheeses. LWT Food Sci. Technol. 42:9-16. http://dx.doi.org/10.1016/j. lwt.2008.07.003.

Kuo, M.-I., Y.-C. Wang, S. Gunasekaran, and N. F. Olson. 2001. Effect of heat treatments on the meltability of cheeses. J. Dairy Sci. 84:1937-1943.

Lelièvre, J. 1995. Whey proteins in cheese - An overview. Pages 359365 in Chemistry of Structure-Function Relationships in Cheese. Advances in Experimental Medicine and Biology. Vol. 367. E. L. Malin and M. H. Tunick, ed. Plenum Press, New York, NY.

Lucey, J. A. 2008. Some perspectives on the use of cheese as a food ingredient. Dairy Sci. Technol. 88:573-594. http://dx.doi. org/10.1051/dst:2008010.

Lucey, J. A., M. E. Johnson, and D. S. Horne. 2003. Invited review: Perspectives on the basis of the rheology and texture properties of cheese. J. Dairy Sci. 86:2725-2743.

Lucey, J. A., R. Mishra, A. Hassan, and M. E. Johnson. 2005. Rheological and calcium equilibrium changes during the ripening of Ched- dar cheese. Int. Dairy J. 15:645-653. http://dx.doi.org/10.1016/j. idairyj.2004.08.018

Marchesseau, S., E. Gastaldi, A. Lagaude, and J.-L. Cuq. 1997. Influence of $\mathrm{pH}$ on protein interactions and microstructure of process cheese. J. Dairy Sci. 80:1483-1489.

Marshall, R. T. 1992. Standard Methods for the Examination of Dairy Products. 16th ed. American Public Health Association, Washington, DC.

Masi, P., and F. Addeo. 1986. An examination of some mechanical properties of a group of Italian cheeses and their relation to structure and conditions of manufacture. J. Food Eng. 5:217-229.

McMahon, D. J., R. L. Fife, and C. J. Oberg. 1999. Water partitioning in Mozzarella cheese and its relationship to cheese meltability. J. Dairy Sci. 82:1361-1369.

McMahon, D. J., B. Paulson, and C. J. Oberg. 2005. Influence of calcium, $\mathrm{pH}$ and moisture on protein matrix structure and functionality in direct-acidified nonfat Mozzarella cheese. J. Dairy Sci. 88:3754-3763.

Mead, D., and P. Roupas. 2001. Effect of incorporation of denatured whey proteins on chemical composition and functionality of pizza cheese. Aust. J. Dairy Technol. 56:19-23.

Metzger, L. E., and D. M. Barbano. 1999. Measurement of postmelt chewiness of Mozzarella cheese. J. Dairy Sci. 82:2274-2279.

Metzger, L. E., D. M. Barbano, and P. S. Kindstedt. 2001. Effect of milk preacidification on low fat Mozzarella cheese: III. Post-melt chewiness and whiteness. J. Dairy Sci. 84:1357-1366.

Ni, H., and S. Guansekaran. 2004. Image processing algorithm for cheese shred evaluation. J. Food Eng. 61:37-45. http://dx.doi. org/10.1016/S0260-8774(03)00186-9.

O'Mahony, J. A., J. A. Lucey, and P. L. H. McSweeney. 2005. Chymosin-mediated proteolysis, calcium solubilization, and texture development during the ripening of Cheddar cheese. J. Dairy Sci. 88:3101-3114.

O'Mahony, J. A., P. L. H. McSweeney, and J. A. Lucey. 2006. A model system for studying the effects of colloidal calcium phosphate concentration on the rheological properties of Cheddar cheese. J. Dairy Sci. 89:892-904.

Pastorino, A. J., R. I. Dave, C. J. Oberg, and D. J. McMahon. 2002. Temperature effect on structure-opacity relationships of nonfat Mozzarella cheese. J. Dairy Sci. 85:2106-2113.

Punidadas, P., J. Feirtag, and M. A. Tung. 1999. Incorporating whey proteins into Mozzarella cheese. Int. J. Dairy Technol. 52:51-55.

Rémillard, N., and M. Britten. 2011. Quantitative determination of micellar calcium in milk and cheese using acid-base titration. Milchwissenschaft 66:137-140

Schenkel, P., R. Samudrala, and J. Hinrichs. 2011. Fat-reduced semihard cheese enriched with a microparticulated whey protein concentrate: Impact on cheese-making properties and rheological characteristics. Milchwissenschaft 66:43-47.

Steffl, A., M. Hafenmaier, A. Hechler, and J. Hinrichs. 1999. Influence of whey protein particles on the renneting properties of milk. Milchwissenschaft 54:510-513.

Stenz, B., A. Höglmeier, U. Fischer, S. Röck, and U. Kulozik. 2006. Comparison of the melting properties of cheese by means of meltability tests and rheological measurements. Milchwissenschaft 61:304-307.

Vithanage, C. R., M. J. Grimson, and B. G. Smith. 2009. The effect of temperature on the rheology of butter, a spreadable blend and spreads. J. Texture Stud. 40:346-369.

Watkinson, P., C. Coker, R. Crawford, C. Dodds, K. Johnston, A. McKenna, and N. White. 2001. Effect of cheese $\mathrm{pH}$ and ripening time on model cheese textural properties and proteolysis. Int. Dairy J. 11:455-464.

Yang, X., N. R. Rogers, T. K. Berry, and E. A. Foegeding. 2011. Modeling the rheological properties of Cheddar cheese with different fat contents at various temperatures. J. Texture Stud. 42:331348. http://dx.doi.org/10.1111/j.1745-4603.2011.00283.

Zisu, B., and N. P. Shah. 2005. Textural and functional changes in lowfat Mozzarella cheeses in relation to proteolysis and microstructure as influenced by the use of fat replacer, pre-acidification and EPS starter. Int. Dairy J. 15:957-972. 